\title{
Alliteration of the Versions of "Piers Plowman" in Its Bearing on Their Authorship
} Author(s): Mabel Day

Source: The Modern Language Review, Vol. 17, No. 4 (Oct., 1922), pp. 403-409

Published by: Modern Humanities Research Association

Stable URL: http://www.jstor.org/stable/3714281

Accessed: 28-04-2016 22:47 UTC

Your use of the JSTOR archive indicates your acceptance of the Terms \& Conditions of Use, available at

http://about.jstor.org/terms

JSTOR is a not-for-profit service that helps scholars, researchers, and students discover, use, and build upon a wide range of content in a trusted digital archive. We use information technology and tools to increase productivity and facilitate new forms of scholarship. For more information about JSTOR, please contact support@jstor.org.

Modern Humanities Research Association is collaborating with JSTOR to digitize, preserve and extend access to The Modern Language Review 


\section{MISCELLANEOUS NOTES.}

\section{Another Latin Manuscript of the 'Anchen Riwle.'}

In the Modern Language Review for April, 1919, I pointed out that an unnoted Latin manuscript of the Ancren Riwle was to be found in Merton Coll. MS. 44, of the early fourteenth century. The following quotation from the new catalogue of the Royal MSS. of the British Museum will prove that a duplicate of this text is to be found in Royal MS. 7 C. x. (art. 4): "Treatise in eight parts (the last is incomplete) without title, on the "regula interior" for anchorites. A copy is at Oxford, Merton Coll. MS. XLIv, ending at the same point. Beg. 'Recti diligunt te. Canticorum primo: Verba sunt, etc.'

The manuscript in question is written in the early sixteenth century on paper. The fragment given of the eighth book is not indicated separately, though the others are, and though it is no more than a few sentences (breaking off very abruptly), the scribe seems not to recognise its incompleteness. He ends as follows : '...ideo non debetis eucharistiam sumere nisi quindecies in anno.' 'Telos' is written in the same hand at the bottom of the page.

B.M. Royal MS. 7 C. x. makes the fourth Latin text of the Ancren Riwle known. Its survival is the more fortunate because, of the other three copies extant, the Cotton MS. is badly burnt, and the Magdalen MS. entirely omits the eighth book.

LoNDon.

Hope Emily Allen.

\section{Alliteration of the Versions of 'Piers Plowman' in its BEARING ON THEIR AUTHORSHIP.}

In Middle English alliterative verse a striking peculiarity has been noticed, namely, that the alliteration often falls on unstressed syllables, either prefixes or prepositions or similar words which are naturally subordinated in stress to a following word. This was first pointed out by Professor Skeat in his Essay on Alliterative Poetry in Volume III of the Percy Folio, 1868, and in the Preface to Alexander and Dindimus (Early English Text Society, 1878). When investigating this phenomenon with a view to tracing its connexion with the pronunciation of the words in 
question ${ }^{1}, I$ found that it cast an interesting light on the problem of the authorship of the three versions of Piers Plowman.

In general, the whole corpus of unrhymed alliterative poetry follows much the same practice in the choice of the alliterating syllable; e.g. the prefixes con-, per-, pro- always alliterate; words beginning in def-, with the exception of defence, defend, always alliterate on the root; words beginning in rel-alliterate on the prefix; though the prefixes be-and for- frequently alliterate, to- and with- only do so when forming adverbs or prepositions, and so on. But certain peculiarities can be noted, which divide certain works. For example, in Richard the Redeless there is no alliteration of the prefix be-, and none of prepositions, both of which characteristics are marked features of all parts of Piers Plowman. Again, Morte Arthure can be distinguished from Troy Book (cp. Dr Giles in Cambridge History of Literature, Vol. II, p. 118) by its use of secondhalf lines where the two stresses seem to fall on the prefix and root of the same word, e.g. 1377 'that thus hym persuede,' 3559 'I salle it revenge' (a feature also of the rhymed alliterative poems); by its frequent shifting of the alliteration from the third to the fourth stress of the line, e.g. 2202 ' He broches euene thorowe the byerne, and the sadille bristes'; and by its alliteration of the adverb so in such lines as 136 'so Crist mott me helpe.'

Professor Manly divides Piers Plowman into five parts, which he attributes to as many different authors, namely, Passus $i$ to viii of the A-text $\left(A_{1}\right)$, Passus ix to xii. 55 of the A-text $\left(A_{2}\right)$, xii. 56-117 of the A-text (John But), the B-text (B), and the C-text (C). Now the work done by the reviser of the A-text falls into two parts: first, the revision and expansion of A. i-xi (Passus xii being omitted from the revised version in $\mathrm{B}$ ), and secondly the continuation of the poem. I propose to divide the $B$-text here, calling the first-part $B_{1}$, and the second, i.e. Passus $\mathrm{xi}-\mathrm{xx}, \mathrm{B}_{2}$; for it is especially between these two parts that $I$ have noticed striking differences of alliteration.

The alliteration of prepositions, etc. is a much more marked feature of $B_{2}$, and after it of $A_{1}$ and $C$, than of $A_{2}$ and $B_{1}$, as the Appendix to this note shows. Also, it may be seen that in the different sections different prepositions alliterate. In the case of the following words in particular, the uses of the sections can be distinguished:

and alliterates 7 timesin $B_{2}$, and once only in $A_{1}, B_{1}$, and $C$ respectively ${ }^{2}$.

1 In an unpublished thesis on 'Early Middle English Word-Stress Investigated on the Basis of the Unrhymed Alliterative Poems,' London, 1921.

2 That is to say, except where the line in $C$ is taken over from $B_{2}$. The same is to be understood of all references in this note; they denote the text in which the word first occurs. 
before alliterates in $\mathrm{A}_{1}$ (twice), $\mathrm{B}_{2}$ (4times), $\mathrm{C}$ ( 5 times); but not in $A_{2}$ or $B_{1}$; note especially C. iii. 100 'And fastingdayes to frete by-for noon, and drynke,' which is altered from B. ii. 95 'ar ful tyme were.'

but alliterates in $B_{1}$ (twice), $B_{2}$ (7 times), $C$ (4t times), but not in either part of the A-text, except the doubtful Pr. 63. In the case of such a line as A. viii. 70 'bote he habbe neode,' there is no word following but which has more right to the alliteration. C. iii. 141 ' bote $3 \mathrm{e}$ a-mende the sonnere,' is altered from A. ii. $95=\mathrm{B}$. ii. 127 ' by god that me made.'.

for plays an important part in distinguishing between the sections. It alliterates in $A_{1}$ (10 times), $B_{2}$ (15 times), and $C$ (11 or 12 times), but not in $A_{2}$, and once only in $B_{1}$. Note especially $A$. vii. 2 'That mihte folwen us vch a fote forte that we come there,' which becomes in $\mathrm{B}_{1}$ 'thus this folke hem mened,' and again in $\mathrm{C}$ 'for drede of mys-tornynge.' Again, A. viii. 32-3,

Pore widewes that wolde beo none wyues aftur

Fynde suche heore foode for godes loue of heuene,

is telescoped in $B_{1}$ into

Pore peple and prisounes fynden hem here fode, and again expanded in $\mathrm{C}$ into

Poure puple bedredene and prisones in stockes,

Fynde hem for godes lone.

fro $(m)$ alliterates in $\mathrm{A}_{1}$ (3 times), $\mathrm{B}_{2}$ (twice), and $\mathrm{C}$ (5 times); not in $\mathrm{A}_{2}$ or $\mathrm{B}_{3}$.

save alliterates in $\mathrm{B}_{2}$ only ( 4 times).

to alliterates in $A_{1}$ (twice), $A_{2}$ (4 times), $B_{2}$ (11 times), and $C$ ( 5 times); but not in $B_{1}$, hence distinguishing sharply between $B_{1}$ and $B_{2}$.

while alliterates in $\mathrm{A}_{1}$ (3 times) and $\mathrm{A}_{2}$, but nowhere else; note A. vii. $51-2$,

'Ich a-sente, be seint Iem !' seide the kniht thenne,

'For to worche bi thi word while my lyf dureth,'

ingeniously altered in $\mathrm{C}$ to

and my wyf bothe.

with alliterates in $A_{1}$ (7 times), $B_{1}$ (12 times), $B_{2}$ (19 times), and $C$ (8 times); but only once in $A_{2}$, just at the point where the lines attributed by Professor Manly to John But begin. Its increasing popularity as an alliterating word is shown by $\mathrm{A}$. vii. 18,

And 3 e, loueli ladies with oure longe fyngres,

1 In such cases there is, of course, always the possibility that the line in $\mathrm{C}$ comes from an unprinted variant of $\mathrm{A}$. In the lines quoted under for below, $\mathrm{C}$ seems to be based on a form combining $A$ and $B$. 
which becomes in $\mathrm{C}$

And ze worthly wommen with zoure longe fyngres;

and also A. viii. 29,

And wikkede wones wihtly to amende,

which similarly becomes

And wikkede weyes with here good amende.

It may also be noted that $B_{1}$ alters $A$. viii. 59,

into

To waxen or to wonien whether god lyketh,

That neuere shal wax ne wanye with oute god hymselue.

Hence, from an examination of the Appendix, we may say that the principal alliterating words are : in $\mathrm{A}_{1}$ for, from, so, while, with; in $\mathrm{A}_{2}$ to; in $\mathrm{B}_{1}$ by, with ; in $\mathrm{C}$ before, by, for, from, so, to, and with. In $\mathrm{B}_{2}$ practically all alliterate, the only important exception being while. Specially striking is the absence of alliterating for and to in $\mathrm{B}_{1}$, compared with their frequency in $B_{2}$. The sharp distinctions drawn between the different sections seem to me to constitute a not unnegligible argument in favour of multiple authorship.

As regards the alliteration of words compounded with prefixes, the chief prefixes which concern us in Piers Plowman are the Romance prefixes $d e-$ and $r e$-, and the Germanic prefix be-. Among words compounded with de-, there is great variety of use in $\mathrm{B}_{1}, \mathrm{~B}_{2}$, and $\mathrm{C}$; but $\mathrm{B}_{2}$ is the only text where the alliteration differs in the same word, the cases being 'defende,' xv. 19, 'defende,' xvi. 246 ; 'departen,' xx. 138, 'departable,' xvii. 26. In $A_{2}$, with one exception (defoulen, xi. 60), these words alliterate on the prefix (defendyth, xii. 19 ; distruieth, x. 76; destroyede, xi. 280 ; disputyng, ix. 108); in $A_{1}$, with one exception (dilytede, i. 29) on the root (14 cases in all). The only word common to $A_{1}$ and $A_{2}$ is defend (cp. xii. 19 with vii. 81 ).

Practically all words compounded with re- alliterate on the prefix. Again the only single word which alliterates on both prefix and root is found in $B_{2}$, namely recover, on the prefix in xviii. 350 , xix. 239 , and on the root in xix. 156. Besides this we have root-alliteration in reprove, xii. 138, xviii. 149, and resemble, xvi. 214. The only root-alliterating word not in $\mathrm{B}_{2}$ is 'repugnen,' C. i. 136, where the B-text reads 'inpugnen'; this may well be a scribal variant.

Words compounded with what have been called the 'heavy' prefixes alliterate on the prefix, with some five exceptions. Again, $\mathbf{B}_{2}$ supplies the only examples of the same word alliterating on both prefix and root, namely, confess, on prefix in xi. 76 , xv. 558 , xvii. 295 , and on the root 
in xi. 53 ; conform, on the prefix in xi. 175 , xiii. $208, x v .337$, and on the root in xiii. 213.

From the alliteration of the Germanic prefixes I do not find any conclusion to be drawn, except that $A_{2}$ is the only section of the poem which shows no variation in single words. Words compounded with be-, though on the whole alliterating on the root, show great variation; e.g. in $\mathrm{A}_{1}$ begin, behold, belief; in $\mathrm{B}_{2}$ behind, before, beneath; in $\mathrm{C}$ before, belief, beseech; in $\mathrm{B}_{1}$ believe alliterates twice on the prefix and twice on the root. But all words in $\mathrm{A}_{2}$, namely become, befall, beginning, belief, beseech, betake, alliterate on the root alone.

It is, of course, quite likely that a poet would, in the course of years, change his practice in these particulars. It is evident, as we can see from an examination of the latest poems, that the tendency of the alliterative school as time passed was to discard prefix-alliteration, and a similar tendency may be expected in the work of an individual. Something of the sort may in fact be traced in the Troy Book, and also in Piers Plowman itself, in the case of certain words beginning with de-. But in Piers Plowman the most striking fact about the use of romance prefixes is that only in one part, namely $B_{2}$, did the poet consider himself free to change the alliterating syllable in a single word; neither in $A$, $\mathrm{B}_{1}$, or $\mathrm{C}$ is this done. In the case of the prepositions also, although a poet might very conceivably alter his practice in the matter of allowing them to alliterate, it is not likely that he would at different periods employ different selections of alliterating prepositions.

In both cases, it is between $B_{1}$ and $B_{2}$ that the distinction is clearest, most strikingly in the alliteration of the prepositions for and to. The variety of alliteration found in $\mathrm{B}_{2}$ divides it from all the other texts, and this characteristic is not developed in $\mathrm{C}$ as one might expect if all the parts were due to the same author. $A_{1}$ and $A_{2}$ again differ in their use of prepositions, especially for and with, and in the alliteration of words in de-. $\mathrm{A}_{2}$ and $\mathrm{B}_{1}$ are distinguished by the alliteration of to in the former, and $b y$, but, and especially with, in the latter. For so short a passage as the half canto attributed to John But, this method cannot give any result, although it is striking that again alliterates on $g$ in xi. 150 and on the spirant in xii. 60. But as regards the rest of the poem, I think it can be definitely stated that the evidence of the alliteration of Piers Plowman points towards its being the work of five different hands, and that this evidence is most constraining where it differentiates that part of the B-text which is a revision of the $\mathrm{A}$-text from the later cantos continuing the work. 


\section{APPENDIX.}

Prepositions, Conjunctions, and Adverbs alliterating in Piers Plowman.

(With respect to the lengths of the different parts, $A_{1}$ is 1833 lines, $A_{2}$ (including Passus xii) 751, and $B_{2}$ 4035. $B_{1} I$ estimate at about 1100-1200 lines; the length of $\mathrm{C}$ is extraordinarily hard to ascertain, owing to the manner in which it adopts the B-text with slight alterations, but roughly it may be said to consist of about 2000 or more lines.)

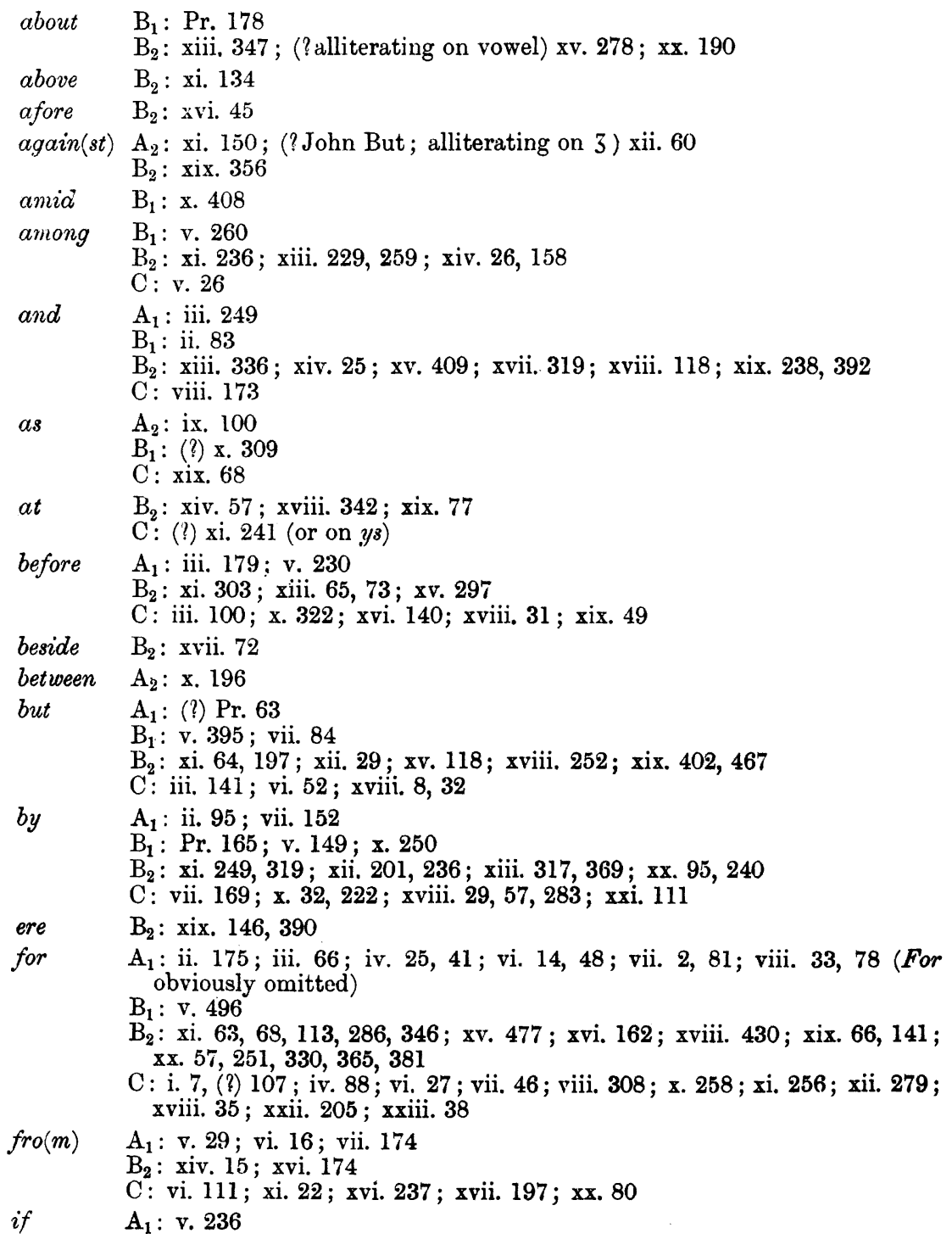


in $\quad A_{1}:$ i. $120 ;$ v. 153

$\mathrm{A}_{2}:$ : 44

$\mathrm{B}_{2}$ : xi. 327 ; xvi. 170,207 ; xvii. 102 ; xx. 277

near $\mathrm{B}_{1}$ : vi. 301

of $\quad \mathrm{B}_{1}$ : (?) $\nabla .633$ (perhaps originally of the poukes ponfolde)

$\mathrm{B}_{2}$ : xiii. 296 ; xv. 565 ; xviii. 122

C: xix. 219,$231 ;$ xx. 98

on $\quad \mathrm{C}:$ xiii. 207

save $\quad \mathrm{B}_{2}$ : xiii. 124 ; xix. 185,434 ; xx. 265

sith $\quad \mathrm{B}_{2}$ : xiv. 142 ; xvii. 31 ; xx. 136

C: x. 115 ; xx. 245

so $\quad A_{1}$ : iii. 92 ; v. 22,122 ; vi. 113 ; viii. 23

$A_{2}$ : ix. 102 ; xi. 295

$\mathrm{B}_{1}$ : v. 376 ; x. 75

$\mathrm{B}_{2}$ : xiii. 205 ; xv. $47,153,288,489$; xvii. 35,158

C: iv. 246 ; xi. 38 ; xii. 297,301 ; xiv. 203 ; xix. 96 ; xx. 33,106

to $\quad A_{1}$ : vii. 197 ; viii. 1

$A_{2}$ : x. 141 ; xi. 62,162 ; xii. 24

$\mathrm{B}_{2}$ : xi. 291,393 ; xiii. $96,125,431$; xvi. 147,148 ; xvii. 76 ; xviii. 238 ; xix. 232 ; xx. 7

C: iii. 124 ; х. 262 ; xi. 181 ; xiii. 187 ; xix. 177

under $\quad \mathrm{B}_{2}$ : xvii. 102

when $\quad \mathrm{A}_{1}$ : iii. 102 ; v. 69

$\mathrm{B}_{2}$ : xi. 226 ; xiv. 62 ; xviii. 412

C: v. 52 ; vii. 160,302

where $\mathrm{A}_{2}$ : ix. 105 ; xii. 40

$\mathrm{B}_{2}$ : xi. 338 ; xvii. 53 ; xx. 3

C: xiv. 34

whether $A_{1}$ : viii. 59

while $\quad \mathrm{A}_{1}$ : ii. 74 ; iii. 29 ; vii. 52

$\mathrm{A}_{2}$ : xi. 101

why $\quad \mathrm{A}_{2}$ : xi. 74, 81

with $\quad A_{1}$; ii. 30 ; iii. 148,252 ; iv. 19 ; v. 25 ; vii. 89 ; viii. 84

$\mathrm{A}_{2}$ : xii. 56 (? John But)

$\mathrm{B}_{1}$ : Pr. 22 ; ii. 90 ; iii. $74,234,238,348$; iv. 33 ; v. 476 ; ix. 113 ; x. 355 , 403,429

$\mathrm{B}_{2}$ : xi. 111,163 ; xiv. 27,292 ; xv. $125,286,446$; xvi. 105, 120, 146, 203, 244,272 ; xvii. 53,69 ; xviii. 228 ; xix. 347,368 ; xx. 167

C: iii. 199 ; ix. 9 ; x. $31,135,196,250$; xix. 261 ; xx. 232

within $\mathrm{B}_{1}$ : x. 149

without $\mathrm{A}_{1}$ : iii. 220

$\mathrm{B}_{1}$ : vii. 55

$\mathrm{B}_{2}$ : xvi. 99 ; xvii. 231.

LONDON.

Mabel Day.

\section{SPENSER'S 'MUIOPOTMOS.'}

In 1914 Mr Percy W. Long contributed an article on the above poem ${ }^{1}$ to which I returned recently when restudying Spenser's minor poems. Mr Long suggested that the allegory obviously underlying this delight-

1 Mod. Lang. Review, vol. Ix, p. 457. 